\title{
PENERAPAN SISTEM PEMBINAAN HALAQAH UNTUK MENINGKATKAN KECERDASAN EMOSIONAL
}

\author{
Armansyah \\ Sekolah Tinggi Ilmy Syariah (STIS) Al-Ittihad Bima \\ armansyah19.boro@gmail.com
}

\begin{abstract}
Abstrak
Perkembangan abad mutakhir menghendaki adanya suatu sistem pendidikan dan pengajaran Islam yang komprehensif. Lembaga pendidikan Islam dituntut untuk mampu ikut berkompetisi dalam upaya menciptakan suatu inovasi kreatif terhadap sistem ataupun metode pembelajaran yang telah ada. Guru sebagai salah satu komponen pendidikan mempunyai peranan sangat penting dalam pencapaian tujuan pendidikan. Halaqah biasanya digunakan untuk mengambarkan sekelompok kecil muslim yang secara rutin menkaji ajaran Islam jumlah peserta berkisar antara 3-12 orang. Pada dasarnya sistem pembinaan halaqah ada tiga tingkatan, mulai dari tahap pertama adalah tahap rahasia dan perseorangan yaitu sejak turunnya wahyu yang pertama Al-qur'an Surat 96, ayat 1-5, tahap kedua adalah tahap terang-terangan kemudian tahap ketiga adalah Tahap untuk umum yaitu seruan dalam skala internasional. Secara praksis penerapan metode halaqah, menjadi ruang meditor bagi setiap orang untuk memahami potensi dirinya mencakup kecerdasan mengenali emosi diri, mengelola emosi, memotivasi diri sendiri, mengenali emosi orang lain, bahkan membina hubungan.
\end{abstract}

Kata Kunci: Sistem, Halaqah, Kecerdasan Emosional

\section{Pendahuluan}

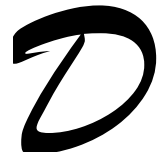

ewasa ini, Perkembangan abad mutakhir menghendaki adanya suatu sistem pendidikan yang komprehensif. lembaga pendidikan dituntut untuk mampu ikut berkompetisi menciptakan suatu inovasi kreatif terhadap sistem ataupun metode pembelajaran yang telah ada. Tentu saja hal itu sangat terkait dengan upaya peningkatan kualitas sumber daya manusia bangsa ini. Pendidikan merupakan sebuah sarana penunjang terhadap kebutuhan hajat hidup manusia. Peserta didik yang umumnya terdiri dari individu yang masih berada pada usia transisi antara anak-anak menuju dewasa, terdapat banyak perubahan psikologis yang terjadi. Salah satu perubahan yang menonjol adalah perubahan emosional peserta didik. Hal tersebut merupakan hal yang alamiah dan wajar, namun perlu dikendalikan dan diawasi, karena tiap individu memiliki kecerdasan emosional yang bervariasi.

Sejak lahir, manusia dibekali dengan beragam kecerdasan oleh Tuhan. Banyak para ahli yang menyebutkan ragam kecerdasan yang dimiliki oleh manusia. Namun, secara garis besar, dikenal ada tiga kecerdasan, yakni kecerdasan intelektual (IQ), kecerdasan emosional (EQ), dan kecerdasan spiritual (SQ). ${ }^{1}$

\footnotetext{
${ }^{1}$ Ahmad Muhaimin Azzet, Mengembangkan Kecerdasan Spiritual Bagi Anak, (Jogjakarta: Kata Hati, 2010),101.
} 
Kemampuan intelektual seolah-olah menjawab persoalan pendidikan dibandingkan dengan kemampuan lainnya. Pendidikan di Indonesia selama ini terlalu menekankan arti penting nilai akademik, kecerdasan otak atau IQ saja. ${ }^{2}$ Mulai dari tingkat Sekolah Dasar sampai dengan Perguruan Tinggi jarang sekali ditemukan pendidikan tentang kecerdasan emosi yang mengajarkan tentang integritas, kejujuran, komitmen, visi, kreatifitas, ketahanan mental, kebijaksanaan, keadilan dsb. Dalam dunia pendidikan atau pengajaran Islam di sekolah yang terjadi selama ini EQ tidak pernah tersentuh. Orientasi pembelajaran pada peserta adalah kecerdasan intelektual, dimana hal ini saja tidak cukup bagi peserta untuk dapat berhasil dalam meniti kehidupan bagi keberhasilan masa depan mereka.

Saat ini studi pengembangan tentang kecerdasan manusia baik IQ (Intelligence Quotient) maupun EQ (Emotional Quotient) telah banyak dilakukan oleh para ahli. IQ memang penting kehadirannya dalam kehidupan manusia, yaitu agar manusia bisa memanfaatkan teknologi dari efisiensi dan efektifitas. Begitu juga EQ yang berperan penting dalam membangun hubungan antar manusia yang efektif, namun tanpa SQ (Spiritual Quotient) yang mengajarkan nilai-nilai kebenaran, maka keberhasilan itu tidak ada gunanya. Hal tersebut di atas membuktikan bahwa IQ dan EQ saja tidaklah cukup membawa diri kita dalam kebahagiaan dan kebenaran yang hakiki ${ }^{3}$

Guru atau murabbi sebagai salah satu komponen pendidikan mempunyai peranan sangat penting dalam pencapaian tujuan pendidikan. Pada kenyataannya, guru dalam menyampaikan pokok permasalahan hanya mampu menjadikan peserta didik memahami materi pokok yang diajarkan tanpa mengamalkannya dalam kehidupan sehari-hari. Oleh karena dengan adanya sistem halaqah biasa disebut juga sistem wetonan, yaitu dimana para santri/peserta mengikuti pelajaran dengan duduk di sekeliling kiai di dalam ruangan (masjid/kelas) dan kiai menjelaskan materi dengan secara kuliah. Para santri menyimak kitab masing masing dan membuat catatan pada kitabnya untuk mensahkan bahwa ilmu itu telah diberikan oleh kiai. ${ }^{4}$ Sistem halaqah atau weton adalah sistem tertua di pesantren dan tentunya merupakan inti pengajaran di suatu pesantren. Semuanya tidak lepas dari konteks historis lahirnya lembaga pendidikan Islam klasik yang pada awalnya bermula pada pengajian di masjid, surau dan langgar dengan mengkaji al-Qur'an, kitab-kitab tasawuf, aqidah, fiqh dan bahasa Arab. Pesantren juga tidak bisa dipisahkan dari masjid, karena telah menjadi bagian pokok yang menghidupkan pesantren yang memberikan nuansa religius/ruh bagi kelangsungan pesantren tersebut.

Selain itu kecerdasan emosi juga menunjuk pada suatu kemampuan untuk memahami perasaan diri masing-masing dan perasaan orang lain, kemampuan memotivasi dirinya sendiri dan menata dengan baik emosiemosi yang muncul dalam dirinya serta dalam

${ }^{2}$ http://bambang sigit widodo.blogspot.co.id/2010/05/pentingnya-kecerdasan-emosional-dalam.html di akses 14 maret 2017.

${ }^{3}$ Ary Ginanjar Agustian, Rahasia Sukses Membangkitkan ESQ Power, (Jakarta : Arga, 2003), 65

${ }^{4}$ Wahidah.2009. Makalah Halaqah (Suatu Sistem Pembelajaran Tradisional) di akses 25 Maret 2017. 
berhubungan dengan orang lain. Oleh karena itu, kecerdasan emosional juga sangat penting karena dapat membantu peserta didik dalam mengatur dan mengontrol diri dalam bersikap. ${ }^{5}$ Sebagaimana Allah swt, berfirman:

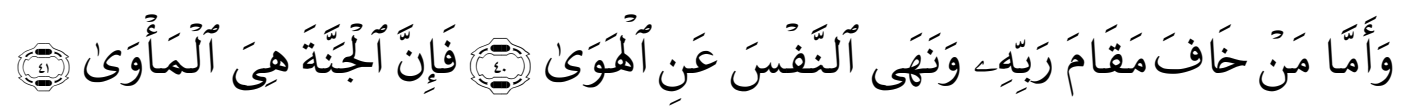

"Dan adapun orang-orang yang takut kepada kebesaran Tuhannya dan menahan diri dari keinginan hawa nafsunya, maka sesungguhnya syurgalah tempat tinggal(nya)" (QS. An-Naziat [79] : 40-41).

Keberadaan halaqah sangat penting untuk keberadaan umat Islam itu sendiri. Dengan terbentuknya kader-kader Islami melalui sistem pendidikan halaqah, maka di dalam tubuh umat akan lahir orang-orang yang senantiasa berdakwah kepada kebenaran. Jika jumlah mereka semakin banyak seiring dengan merebaknya sistem halaqah, maka umat Islam akan menjadi 'sebenar-benarnya umat'. Bukan lagi sekedar bernama 'umat Islam' tapi esensinya jauh dari nilai-nilai Islam seperti yang kita saksikan saat ini.

Dengan merebaknya sistem pendidikan halaqah proses pembentukan umat yang Islami (takwinul ummah) akan mengalami akselarasi, hingga - Insya Allah - umat yang benar-benar Islami akan menjadi kenyataan dalam waktu yang lebih cepat. Hal ini akan berdampak pada kehidupan manusia secara menyeluruh yang lebih berpihak pada nilai-nilai kebenaran dan keadilan. Pada dasarnya keberhasilan peserta didik tidak hanya dari melejitkan kemampuan intelektual saja, akan tetapi kemampuan emosional juga memiliki peranan. Menurut penelitian IQ hanya berperan dalam kehidupan manusia dengan besaran maksimum 20\%, sehingga kecerdasan emosional memiliki peranan penting menentukan keberhasilan seseorang. Sehingga EQ sangat penting. Setinggi-tingginya IQ hanya minimal untuk meraih keberhasilan, kecerdasan emosional yang sesungguhnya mengantarkan seseorang menuju puncak prestasi.

Menurut penelitian dari Daniel Goleman seorang psikolog dari Harvard University bahwa IQ akan dapat bekerja secara efektif apabila seseorang mampu memfungsikan EQnya. Hal ini dibuktikan dalam penelitian yang dilakukan di daerah kumuh pada kondisi kesulitan ekonomi dan ditemukan data hanya sekitar $20 \%$ saja masyarakat yang mempunyai IQ mampu bertahan hidup sedangkan sisanya berasal dari faktor lain termasuk kecerdasan emosi. Kemampuan intelektual hanya merupakan salah satu unsur pendukung keberhasilan sesorang. Apakah keberhasilan ini akan tercapai, tentunya tergantung pada kemampuan sesorang di dalam menggabungkan IQ dan EQ-nya. ${ }^{6} \mathrm{Hal}$ ini berimplikasi dan mempengaruhi berbagai aspek kehidupan manusia baik dalam pendidikan maupun pekerjaannya sehingga mencapai kesuksesan dalam kehidupan di masa yang akan datang.

\footnotetext{
${ }^{5}$ Al-Quran dan Terjemah, (Jakarta: Yayasan Penyelenggara Penerjemah Al-Quran, 1990), 40-41

${ }^{6} \mathrm{http}: / /$ bambang sigit widodo.blogspot.co.id /2010/05/Pentingnya-kecerdasan-emosional-dalam.html di akses 14 Maret 2017.
} 
Berdasarkan uraian di atas bahwa Kecerdasan emosional (EQ) memegang peranan penting bagi kesuksesan seseorang. Namun, masih banyak masyarakat saat ini yang hanya terpaku pada IQ saja. Kecerdasan emosional dapat diukur dari kemampuan seseorang untuk mengenal dirinya sendiri, mengelola emosinya dan memotivasi diri bahkan membina hubungan. Selain itu juga kecerdasaan emosional juga dapat dilihat dari kemampuan seorang merasakan apa yang dirasakan orang lain (empati) dan keluwesan dalam hubungan dengan orang lain.

\section{Tinjuan Tentang Konsep Dasar Sistem Halaqah}

\section{Pengertian Halaqah}

Halaqah berasal dari kata bahasa arab halqah yang berarti kumpulan orang-orang yang duduk melingkar. Jadi halakah maksudnya adalah proses pembelajaran dimana peserta didik melingkari gurunya. Dalam halakah, jumlah peserta peserta berkisar antara 3-12 orang. Halaqah atau usrah adalah sekumpulan orang yang ingin mempelajari dan mengamalkan Islam secara serius. biasanya mereka terbentuk karena kesadaran mereka sendiri untuk mempelajari dan mengamalkan Islam secara bersamasama (amal jama'i). kesadaran itu muncul setelah mereka bersentuhan dan menerima dakwah dari orang mengikuti halaqah/usrah terlebih dahulu, baik melalui forumforum umum, seperti tabligh, seminar, pelatihan atau daurah, maupun karena dakwah interpersonal (dakwah fardiyah). Seacara istilah, halaqah merupakan istilah yang berhubungan dengan dunia pendidikan, khususnya pendidikan atau pengajaran Islam (Tarbiyah Islamiyah). Istilah halaqah (lingkaran) biasanya digunakan untuk mengambarkan sekelompok kecil muslim yang secara rutin menkaji ajaran Islam jumlah peserta berkisar antara 3-12 orang. Mereka mengkaji Islam dengan manhaj (kurikulum) tertentu. Biasanya kurikulum tersebut berasal dari jamaah (organisasi) yang menaungi halakah tersebut. Kalangan lain, halakah disebut juga dengan mentoring, ta'lim, pengajian kelompok,tarbiyah atau sebutan lainnya. ${ }^{7}$

Biasanya peserta halaqah atau usrah di pimpin oleh dan dibimbing oleh seorang murabbi (pembina). Murabbi disebut juga dengan mentor, pembina, ustadz (guru), mas'ul (penanggung jawab) atau naqib (pemimpin). Murabbi bekerjasama dengan peserta halaqah atau usrah untuk mencapai tujuan halaqah yaitu terbentuknya muslim yang Islami dan berkarakter dai (takwinul Islamiyah wada'iyah). ${ }^{8}$ Dalam mencapai tujuan tersebut, murabbi berusaha agar peserta hadir secara rutin dalam pertemuan halaqah tanpa merasa bosan dan jenuh.

\footnotetext{
${ }^{7}$ Satria Hadi Lubis, Menggairahkan Perjalanan, Halaqah Kiat Agar Halaqah Lebih Dahsyat Full Manfaat. (Pro-U Media. Yogyakarta, 2010), 16.

${ }^{8}$ Ibid.
} 


\section{Penerapan Sistem Pembinaan Halaqah}

Pemaknaan terhadap konten wahyu yang pertama diterima Nabi Muhammad SAW, pada tahun $610 \mathrm{M}$ di Gua Hira, sebagaimana disebutklan dalam al-qur'an berikut ini.

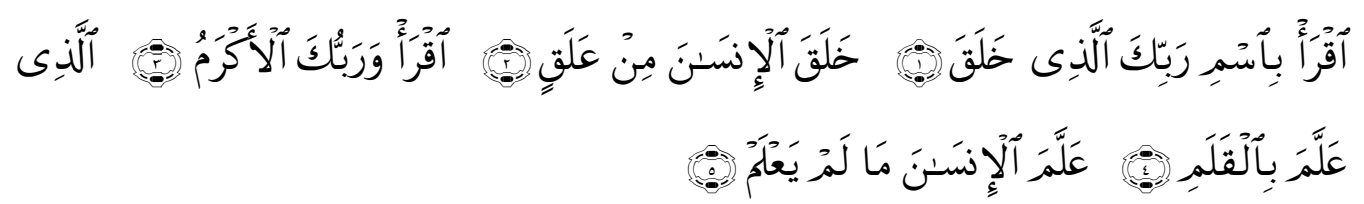

"Bacalah dengan (menyebut) nama Tuhanmu yang Menciptakan, Dia telah menciptakan manusia dari segumpal darah. Bacalah, dan Tuhanmulah yang Maha pemurah, Yang mengajar (manusia) dengan perantaran kalam, Dia mengajar kepada manusia apa yang tidak diketahuinya. Maksudnya" (QS. AlAlaq [96]: 1-5).

Kemudian wahyu yang kedua tertulis dalam ayat al-qur'an:

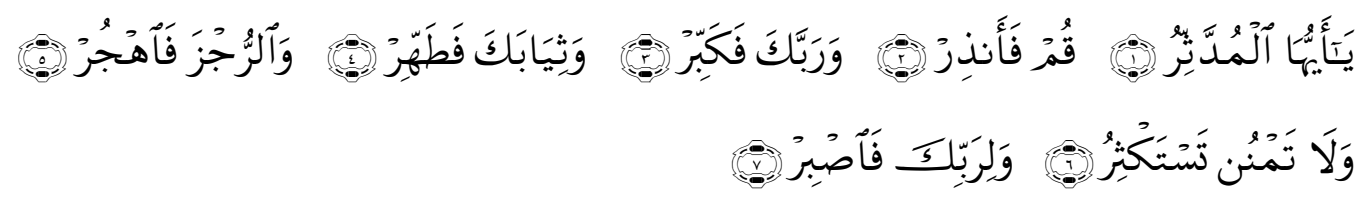

"Hai orang yang berselimut. Bangunlah, lalu berilah peringatan! dan Tuhanmu agungkanlah! dan pakaianmu bersihkanlah dan perbuatan dosa tinggalkanlah dan janganlah kaтu memberi (dengan maksud) memperoleh (balasan) yang lebih banyak dan untuk (memenuhi perintah) Tuhanmu, bersabarlah" (QS. AlMuddatssir [74]: 1-6).

Dengan turunnya wahyu itu Nabi Muhammad telah diberi tugas oleh Allah, supaya bangun melemparkan kain selimut dan menyingsingkan lengan baju untuk memberi peringatan dan pengajaran kepada seluruh umat manusia sebagai tugas suci, tugas mendidik dan mengajarkan Islam. Kemudian kedua wahyu itu diikuti oleh wahyu-wahyu yang lain. Semuanya itu disampaikan dan diajarkan oleh Nabi, mulamula kepada karib kerabatnya dan teman sejawatnya dengan sembunyi-sembunyi. Setelah banyak orang memeluk Islam, lalu Nabi menyediakan rumah Al-Arqam bin Abil Arqam untuk tempat pertemuan sahabat-sahabat dan pengikut pengikutnya.

Penerapan sistem pembinaan halaqah atau pola pendidikan yang dilakukan oleh Rasulullah yaitu dengan tiga tahap. Tahap pertama adalah Tahap rahasia dan perseorangan yaitu sejak turunnya wahyu yang pertama QS. 96, ayat 1-5, dilakukan dengan cara sembunyi-sembunyi dengan memulai dari dirinya sendiri dan keluarga dekatnya. ${ }^{9}$ Mula-mula Rasulullah mendidik istrinya, Khadijah untuk beriman kemudian diikuti oleh anak angkatnya Ali bin Abi Thalib dan Said bin Haritsah

\footnotetext{
${ }^{9}$ Samsul Nizar, Sejarah Pendidikan Islam (Menelusuri jejak sejarah pendidikan Era Rasulullah Sampai Indonesia (Jakarta : Kencana, 2007), 5-6.
} 
selanjutnya diikuti oleh sahabat-sahabat karib Rasullulah. Sebagai lembaga pendidikan dan pusat pendidikan Islam yang pertama pada era awal ini adalah, rumah Arqam ibn Arqam.

Tahap kedua adalah Tahap terang-terangan yaitu berselang tiga tahun sampai turunnya wahyu berikutnya, yang memerintahkan dakwah secara terbuka dan terangterangan. Perintah dakwah secara terang-terangan tersebut seiring dengan jumlah sahabat yang semakin banyak dan untuk meningkatkan jangkauan saluran dakwah, di samping itu keberadaan rumah Arqam bin Arqam sebagai pusat lembaga pendidikan Islam sudah diketahui oleh Quffar Quraisy.

Tahap ketiga adalah Tahap untuk umum yaitu seruan dalam skala internasional tersebut, didasarkan kepada perintah Allah SWT. ${ }^{10}$

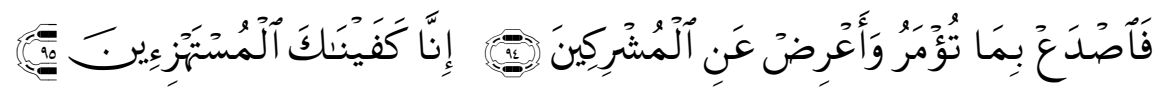

"Maka sampaikanlah olehmu secara terang-terangan segala apa yang diperintahkan (kepadamu) dan berpalinglah dari orang-orang yang musyrik, Sesungguhnya Kami memelihara kamu daripada (kejahatan) orang-orang yang memperolok-olokkan kamu” (QS al-Hijr Ayat [15]: 94-95).

Sebagai tindak lanjut dari perintah tersebut, Pada musim haji Rasulullah mendatangi kemah para jemaah haji. Pada awalnya tidak banyak yang menerima, kecuali kelompok jemaah haji dari Yastrib, yang menerima dakwah secara antusias. Dari sinilah sinar Islam memancar keluar Mekkah. Inilah bentuk dakwah Rasulullah secara umum, dakwah kepada setiap ummat manusia yang datang dari seluruh penjuru bumi berhaji ke Mekkah.

\section{Prinsip Dasar Sistem Pembinaan Halaqah dalam Islam}

Merujuk sejarah pendidikan Islam, pada masa pembinaan pendidikan agama Islam di Makkah oleh Nabi Muhammad, secara subtantif telah meletakan dasar tentang pelaksanaan sistem pembinaan halaqah. Kondisi ini dijelaskan dalam konteks pengajaran al Qur'an yang dilakukan oleh Nabi Muhammad SAW yang menunjukan prinsip pembinaan secara halaqah dalam majelis Ilmu, misalnya para sahabat mendengarkan dan menyimak dengan seksama terkait penyampaian wahyu oleh Nabi Muhammad SAW., ataupun memutuskan segala persoalan yang berkenaan dengan hukum, tauhid, social-kehidupan masyarakat dengan menempatkan rasulullah sebagai central informasi yang dapat memutuskan segala bentuk permasalahan berdasarkan alqur'an nulkarim. Disamping itu Nabi Muhamad SAW, mengajarkan tauhid kepada

\footnotetext{
${ }^{10}$ Al-Quran dan Terjemah, (Jakarta: Yayasan Penyelenggara Penerjemah Al-Quran, 1990), 94-95.
} 
umatnya. ${ }^{11}$ Intinya pendidikan dan pengajaran yang diberikan Nabi selama di Makkah ialah pendidikan keagamaan dan akhlak serta menganjurkan kepada manusia, supaya mempergunakan akal pikirannya memperhatikan kejadian manusia, hewan, tumbuhtumbuhan dan alam semesta seagai anjuran pendidikan 'aqliyah yang menekankan polarisasi sistem pembinaan secara halaqah dalam majelis ilmu terlebih kepada para sahabatnya. Adapun Pembinaan pendidikan Islam pada masa Makkah meliputi:

a. Pendidikan keagamaan, yaitu hendaklah membaca dengan nama Allah semata jangan dipersekutukan dengan nama selain-Nya.

b. Pendidikan aqliyah, yaitu mempelajari kejadian manusia dari segumpal darah dan kejadian alam semesta.

c. Pendidikan akhlak, yaitu Nabi Muhammad SAW mengajarkan kepada sahabatnya agar berakhlak baik sesuai dengan ajaran tauhid.

d. Pendidikan jasmani, yaitu mementingkan kebersihan pakaian, badan dan tempat kediaman.

Setiap usaha pendidikan sangat memerlukan dasar sebagai landasan berpijak dalam penentuan materi, interaksi, inovasi dan cita-citanya. Oleh karena itu, seluruh aktivitas pendidikan meliputi penyusunan konsep teoritis dan pelaksanaan operasionalnya harus memiliki dasar yang kokoh. Menurut, Hasan Langgulung ada lima sumber nilai yang diakui dalam Islam ${ }^{12}$ yaitu :

a. Al-Qur'an adalah kitab Allah SWT yang ditturunkan untuk menunjukkan manusia kepada keadaan yang lebih baik. Ayat-ayat al-Qur'an terlalu banyak dalam hal ini. Firman Allah : "Kami tidak menurunkan al-Qur'an kecuali agar engkau menerangkan kepada mereka hal-hal yang mereka perselisihkan dan juga sebagai petunjuk dan rahmat bagi kaum yang beriman" Juga Firman-Nya : "Inilah kitab yang Kami turunkan kepadamu, lagi diberkati agar mereka memikirkan ayat-ayatNya dan orang-orang yang berfikir itu ingat". Selain firman-firman ${ }^{13}$ Allah di atas al-Qur'an juga mempunyai keistimewaan dalam pendidikan yaitu menghormati akal manusia, bimbingan ilmiah, tidak menentang fitrah manusia, penggunaan cerita-cerita untuk tujuan pendidikan, memelihara kebutuhan-kebutuhan sosial dan lain sebagainya.

b. Sunnah Nabi Sesuatu yang disandarkan kepada Nabi saw. baik perkataan, perbuatan dan persetujuannya.

${ }^{11}$ Ali rif'an. 2012., Konsep pendidikan Islam di masa Rasulullah: Periode makkah dan madinah di akses 15 Maret 2017.

${ }^{12}$ Hasan Langgulung Beberapa Pemikiran Pendidikan Islam, (Bandung : al-Ma'arif, Cet. II, 1995), 96100.

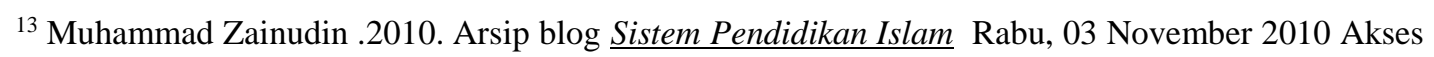
11 Maret 2017. 
c. Qiyas Artinya membandingkan masalah yang disebutkan oleh al-Qur'an atau sunnah dengan masalah yang dihadapi umat Islam tetapi nash yang tegas dalam al-Qur'an tidak ada.

d. Kemaslahatan umum yang tidak bertentangan dengan nash

e. Ijma' ulama dan ahli pikir Islam yang sesuai dengan sumber dasar al-Qur'an dan sunnah Nabi.

\section{Makna Kerdasan Emosi dan Kecerdasan Spiritual dalam Ranah Sistem Pembinaan Halaqah}

Steiner, menjelaskan kecerdasan Emosional adalah suatu kemampuan yang dapat mengerti emosi diri sendiri dan orang lain, serta mengetahui bagaimana emosi diri sendiri terekspresikan untuk meningkatkan maksimal etis sebagai kekuatan pribadi. Senada dengan definisi tersebut, Davies, Stankov, dan Roberts dalam Mayer dan Solovey (mengungkapkan kecerdasan emosi sebagai kemampuan untuk memantau dan mengendalikan perasaan sendiri dan orang lain, dan menggunakan perasaan-perasaan itu untuk memadu pikiran dan tindakan $^{14}$

Sedangkan dalam terminologi Islam, dapat dikatakan bahwa kecerdasan emosional adalah kecerdasan yang bertumpu pada qalb. Qalb inilah yang sebenarnya merupakan pusat kendali semua gerak anggota tubuh manusia. Ia adalah raja bagi semua anggota tubuh yang lain. Semua aktivitas manusia berada di bawah kendalinya. Jika qalb ini sudah baik, maka gerak dan aktivitas anggota tubuh yang lain akan baik pula. Demikian juga sebaliknya ${ }^{15}$ Riwayat Al-Bukhari al-Ja'fi, Al-Bukhari, bi Hasyiati Sanadi yang arinya "Ilmu sebelum perkataan dan perbuatan,sesuai dengan perkataan Allah (ketahuilah tiada Tuhan selain Allah) Ia memulainya dengan Ilmu sesungghunya ulama adalah pewaris para nabi, mereka mewarisi ilmu dengan sangat lengkap, barang siapa yang menempuh jalan (proses belajar dan mengajar) untuk menuntut ilmu maka Allah akan memudahkan baginya jalan menuju surga."

Kecerdasan emosi dapat menempatkan emosi seseorang pada porsi yang tepat, memilah kepuasan dan mengatur suasana hati. Koordinasi suasana hati adalah inti dari hubungan sosial yang baik. Apabila seseorang pandai menyesuaikan diri dengan suasana hati individu yang lain atau dapat berempati, orang tersebut akan memiliki tingkat emosionalitas yang baik dan akan lebih mudah menyesuaikan diri dalam pergaulan sosial serta lingkungannya. Sedangkan kecerdasan spiritual adalah kecerdasan qalbu yang berhubungan dengan kualitas batin seseorang. Kecerdasan ini mengarahkan sesorang untuk berbuat lebih manusiawi, sehingga dapat menjangkau nilai-nilai luhur. Al-Qur'an menyatakan bahwa dalam surah sebagai berikut;

\footnotetext{
${ }^{14} \mathrm{http} / / /$ elajar psikologi.com/pengertian-kecerdasan-emosional-eq di akses 12 maret 2017.

15 Al Bukhari al-Ja'fi, Al-Bukhari, bin Hasyiati Sanadi, (Beirut: Dar al-Fikr, 1991), 24
} 


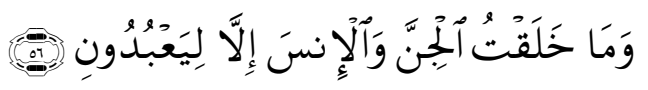

"Tidaklah Aku ciptakan Jin dan manusia itu melainkan beribadah kepadaKu”.Tafsir ayat ini menunjukkan bahwa, manusia dan jin adalah mutlak beribadah kepada Tuhan" (QS. Adz-zaariyat ayat [51]: 56).

Kecerdasan spiritual yang diyakini sebagai kecerdasan yang mampu memfungsikan kecerdasan intelektual dan kecerdasan emosi secara efektif dan kecerdasan spiritual merupakan kecerdasan tertinggi. Hal ini harus diraih dalam suatu lingkungan yang sarat dengan cinta dan kepedulian Ary Ginanjar Agustian mengatakan bahwa: "Kecerdasan spiritual ialah suatu kemampuan untuk memberi makna ibadah terhadap setiap perilaku dan kegiatan, melalui langkah-langkah dan pemikiran yang bersifat fitrah, menuju manusia yang seutuhnya (hanif) dan memiliki pola pemikiran tauhidi (integralistik) serta berprinsip "hanya karena Tuhan". Sebagaimana Ayat berikut ini juga memberikan dorongan kepada manusia agar ia memiliki kecerdasan pribadi, yaitu pada Surat al-Baqarah.

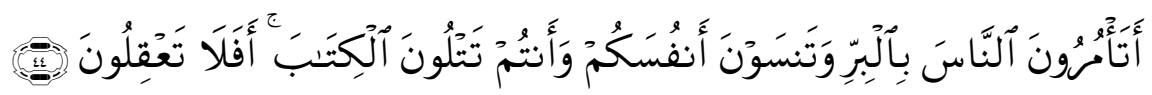

"Mengapa kamu suruh orang lain (mengerjakan) kebajikan, sedang kamu melupakan diri (kewajiban)mu sendiri padahal kamu membaca Al-Kitab (Taurat) Maka tidakkah kamu berpikir" (QS. Al-Baqarah [2] : 44).

Selanjutnya, Allah SWT., juga mengingatkan kepada manusia agar memiliki kemampuan introspeksi terhadap dirinya sendri, Juga memahami hak dan kewajibannya sebagaiman firmannya.

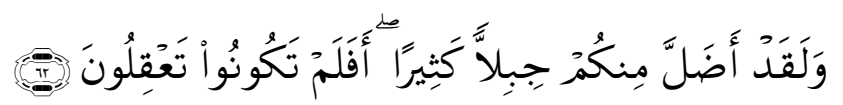

"Sesungguhnya syaitan itu telah menyesatkan sebahagian besar diantaramu, Maka Apakah kamu tidak memikirkan” (QS. Yasin [36]: 62).

Sederhananya, bermkna memberikan peringatan agar manusia memilki kemampuan membentengi diri dari godaan setan. Mengingatkan kepada manusia, sebelum menyesal, untuk menggunakan potensi akal dan pendengarannya dalam meningkatkan keimanannya.

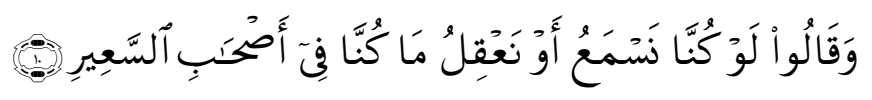

"Dan mereka berkata: "Sekiranya Kami mendengarkan atau memikirkan (peringatan itu) niscaya tidaklah Kami Termasuk penghuni-penghuni neraka yang menyala-nyala" (QS. al-Mulk [67] :10).

Menurut Ary Ginanjar Agustian menekankan bahwa kecerdasan spiritual adalah perilaku atau kegiatan yang kita lakukan merupakan ibadah kepada Tuhan. Dengan demikian, kecerdasan spiritual menurut Ary Ginanjar Agustian, haruslah disandarkan kepada 
Tuhan dalam segala aktivitas kehidupan untuk mendapatkan suasana ibadah dalam aktivitas manusia. ${ }^{16}$

\section{Aspek-Aspek dalam Pembentukan Kecerdasan Emosi dalam Penerapan Pembinaan Sisstem Halaqah}

Sampai sekarang belum ada alat ukur yang dapat digunakan untuk mengukur kecerdasan emosi seseorang. Walaupun demikian, ada beberapa ciri-ciri yang mengindikasi seseorang memiliki kecerdasan emosional. Goleman menyatakan bahwa secara umum ciriciri seseorang memiliki kecerdasan emosi adalah mampu memotivasi diri sendiri, bertahan menghadapi frustasi, mengendalikan dorongan hati dan tidak melebih-lebihkan kesenangan, mengatur suasana hati dan menjaga agar beban stres tidak melumpuhkan kemampuan berfikir serta berempati dan berdoa. Lebih lanjut Goleman sebagaiman dikutip Salovey mengemukakan lima aspek kecerdasan emosi:

a. Mengenali emosi diri, yaitu kemampuan individu yang berfungsi untuk memantau perasaan dari waktu ke waktu, mencermati perasaan yang muncul. Ketidakmampuan untuk mencermati perasaan yang sesungguhnya menandakan bahwa orang berada dalam kekuasaan emosi. Kemampuan mengenali diri sendiri meliputi kesadaran diri.

b. Mengelola emosi, yaitu kemampuan untuk menghibur diri sendiri, melepas kecemasan, kemurungan atau ketersinggungan dan akibat-akibat yang timbul karena kegagalan ketrampilan emosi dasar. Orang yang buruk kemampuan dalam ketrampilan ini akan terus menerus bernaung melawan perasaan murung, sementara mereka yang pintar akan dapat bangkit kembali jauh lebih cepat. Kemampuan mengelola emosi meliputi kemampuan penguasaan diri dan kemampuan menenangkan kembali. ${ }^{17}$

c. Memotivasi diri sendiri, yaitu kemampuan untuk mengatur emosi merupakan alat untuk mencapai tujuan dan sangat penting untuk memotivasi dan menguasai diri. Orang yang memiliki keterampilan ini cenderung jauh lebih produktif dan efektif dalam upaya apapun yang dikerjakannya. Kemampuan ini didasari oleh kemampuan mengendalikan emosi, yaitu menahan diri terhadap kepuasan dan mengendalikan dorongan hati. Kemampuan ini meliputi: pengendalian dorongan hati, kekuatan berfikir positif dan optimis.

d. Mengenali emosi orang lain, kemampuan ini disebut empati, yaitu kemampuan yang bergantung pada kesadaran diri emosional, kemampuan ini merupakan ketrampilan dasar dalam bersosial. Orang empatik lebih mampu menangkap sinyal-sinyal sosial

\footnotetext{
${ }^{16} \mathrm{https} / /$ Dr. Arif Zulkifli Consultan lingkungan dan energy /bangazul.com/kecerdasan-spritual/ di akses 10 Maret 2017.

${ }^{17}$ http://arnimabruria.blogspot.co.id/2012/08/aspek-aspek-kecerdasan-emosi html di akses 12 Maret 2017.
} 
tersembunyi yang mengisyaratkan apa yang dibutuhkan orang atau dikehendaki orang lain.

e. Membina hubungan. Seni membina hubungan sosial merupakan keterampilan mengelola emosi orang lain, meliputi ketrampilan social yang menunjang popularitas, kepemimpinan dan keberhasilan hubungan antar pribadi.

Sedikit berbeda dengan pendapat Goleman, menurut Tridhonanto aspek kecerdasan emosi adalah:

a. Kecakapan pribadi, yakni kemampuan mengelola diri sendiri.

b. Kecakapan sosial, yakni kemampuan menangani suatu hubungan.

c. Keterampilan sosial, yakni kemampuan menggugah tanggapan yang dikehendaki orang lain.

Aspek aspek kecerdasan emosi yang dikemukakan Goleman setelah peneliti kaji lebih jauh merupakan jabaran dari pendapat Al Tridhonanto Dalam kecakapan pribadi menurut Al Tridhonanto terdapat aspek-aspek kecerdasan emosi menurut Goleman yaitu; mengenali emosi diri, mengelola emosi diri dan memotivasi diri sendiri. Kemudian dalam kecakapan sosial. Menurut Al Tridhonanto juga terdapat aspek kecerdasan emosi menurut Goleman yaitu mengenali emosi orang lain. Sedangkan ketrampilan social menurut Al Tridhonanto terdapat aspek kecerdasan emosi menurut Goleman yaitu membina hubungan.

\section{Faktor-Faktor yang Mempengaruhi Kecerdasan Emosi dalam Pelaksanaan Sistem Halaqah}

Kecerdasan emosi tidak ditentukan sejak lahir tetapi dapat dilakukan melalui proses pembelajaran. Ada beberapa faktor yang mempengaruhi kecerdasan emosi individu menurut Goleman,yaitu:

a. Lingkungan keluarga. Kehidupan keluarga merupakan sekolah pertama dalam mempelajari emosi. Peran serta orang tua sangat dibutuhkan karena orang tua adalah subyek pertama yang perilakunya diidentifikasi, diinternalisasi yang pada akhirnya akan menjadi bagian dari kepribadian anak. Kecerdasan emosi ini dapat diajarkan pada saat anak masih bayi dengan contoh-contoh ekspresi. Kehidupan emosi yang dipupuk dalam keluarga sangat berguna bagi anak kelak di kemudian hari, sebagai contoh: melatih kebiasaan hidup disiplin bertanggung jawab, kemampuan berempati, kepedulian, dan sebagainya. ${ }^{18} \mathrm{Hal}$ ini akan menjadikan anak menjadi lebih mudah untuk menangani dan menenangkan diri dalam menghadapi permasalahan, sehingga anak-anak dapat berkonsentrasi dengan baik dan tidak memiliki banyak masalah tingkah laku seperti tingkah laku kasar dan negatif.

\footnotetext{
${ }^{18} \mathrm{http} / / /$ arnimabruria.blogspot.co.id/2012/08/faktor-faktor-yang-mempengaruhi .html di akses 10
} Maret 2017. 
b. Lingkungan non keluarga. Dalam hal ini adalah lingkungan masyarakat dan lingkungan penduduk. Kecerdasan emosi ini berkembang sejalan dengan perkembangan fisik dan mental anak. Pembelajaran ini biasanya ditunjukkan dalam aktivitas bermain anak seperti bermain peran. Anak berperan sebagai individu di luar dirinya dengan emosi yang menyertainya sehingga anak akan mulai belajar mengerti keadaan orang lain. Pengembangan kecerdasan emosi dapat ditingkatkan melalui berbagai macam bentuk pelatihan diantaranya adalah pelatihan asertivitas, empati dan masih banyak lagi bentuk pelatihan yang lainnya.

Menurut Goleman dalam Le bahwa faktor-faktor yang mempengaruhi kecerdasan emosi antara lain:

a. Fisik. Secara fisik bagian yang paling menentukan atau paling berpengaruh terhadap kecerdasan emosi seseorang adalah anatomi saraf emosinya. Bagian otak yang digunakan untuk berfikir yaitu konteks (kadang kadang disebut juga neo konteks). Sebagai bagian yang berada dibagian otak yang mengurusi emosi yaitu system limbik, tetapi sesungguhnya antara kedua bagian inilah yang menentukan kecerdasan emosi seseorang.

1) Konteks. Bagian ini berupa bagian berlipat-lipat kira kira 3 milimeter yang membungkus hemisfer serebral dalam otak. Konteks berperan penting dalam memahami sesuatu secara mendalam, menganalisis mengapa mengalami perasaan tertentu dan selanjutnya berbuat sesuatu untuk mengatasinya. Konteks khusus lobus prefrontal, dapat bertindak sebagai saklar peredam yang memberi arti terhadap situasi emosi sebelum berbuat sesuatu.

2) Sistem limbik. Bagian ini sering disebut sebagai emosi otak yang letaknya jauh didalam hemisfer otak besar dan terutama bertanggung jawab atas pengaturan emosi dan implus. Sistem limbik meliputi hippocampus, tempat berlangsungnya proses pembelajaran emosi dan tempat disimpannya emosi. Selain itu ada dalam yang dipandang sebagai pusat pengendalian emosi pada otak.

b. Psikis. Kecerdasan emosi selain dipengaruhi oleh kepribadian individu, juga dapat dipupuk dan diperkuat dalam diri individu. Berdasarkan uraian tersebut dapat disimpulkan bahwa terdapat dua faktor yang dapat mempengaruhi kecerdasan emosi seseorang yaitu secara fisik dan psikis. Secara fisik terletak dibagian otak yaitu konteks dan sistem limbik, secara psikis diantarnya meliputi lingkungan keluarga dan lingkungan non keluarga.

\section{Penutup}

Berdasarkan uraian atas, maka dapat disimpulkan bahwa, halaqah atau usrah merupakan istilah yang berhubungan dengan dunia pendidikan, khususnya pendidikan atau pengajaran Islam (Tarbiyah Islamiyah). Istilah halaqah (lingkaran) biasanya digunakan untuk mengambarkan sekelompok kecil muslim yang secara rutin menkaji ajaran Islam jumlah 
peserta berkisar antara 3-12 orang. Mereka mengkaji Islam dengan manhaj (kurikulum) tertentu.

Dengan adanya unsur-unsur penerapan sistem pembinaan halaqah terhadap kecerdasan emosional. Dalam masa pembinaan pendidikan agama Islam di Makkah Nabi Muhammad juga mengajarkan al-Qur'an karena al-Qur'an merupakan inti sari dan sumber pokok ajaran Islam. Disamping itu Nabi Muhammad SAW, mengajarkan tauhid kepada umatnya. Oleh karena demikian, intinya pendidikan dan pengajaran yang diberikan Nabi selama di Makkah ialah pendidikan keagamaan dan akhlak serta menganjurkan kepada manusia, supaya mempergunakan akal pikirannya memperhatikan kejadian manusia, hewan, tumbuhtumbuhan dan alam semesta seagai anjuran pendidikan 'aqliyah dan ilmiyah.

Dalam terminologi Islam, dapat dikatakan bahwa kecerdasan emosional adalah kecerdasan yang bertumpu pada qalb. Qalb inilah yang sebenarnya merupakan pusat kendali semua gerak anggota tubuh manusia. Ia adalah raja bagi semua anggota tubuh yang lain. Semua aktivitas manusia berada di bawah kendalinya. Jika qalb ini sudah baik, maka gerak dan aktivitas anggota tubuh yang lain akan baik pula. Tidak hanya itu kecerdasan emosional dapat diukur dari kemampuan seseorang untuk mengenal dirinya sendiri, mengelola emosinya dan memotivasi diri bahkan membina hubungan. Selain itu juga kecerdasaan emosional juga dapat dilihat dari kemampuan seorang merasakan apa yang dirasakan orang lain (Empati).

\section{Daftar Pustaka}

Al-Quran dan Terjemah, Jakarta: Yayasan Penyelenggara Penerjemah Al-Quran, 1990.

Al Bukhari al-Ja'fi, Al-Bukhari, bin Hasyiati Sanadi, (Beirut: Dar al-Fikr, 1991), Jilid I

Ali rif'an. 2012., Konsep pendidikan Islam di masa Rasulullah: Periode makkah dan madinah.

Ahmad Muhaimin Azzet, Mengembangkan Kecerdasan Spiritual Bagi Anak, (Jogjakarta: Kata Hati, 2010).

Ary Ginanjar Agustian, Rahasia Sukses Membangkitkan ESQ Power, (Jakarta : Arga, 2003).

Hasan Langgulung Beberapa Pemikiran Pendidikan Islam, Bandung : al-Ma'arif, Cet. II, 1995.

Muhammad Zainudin .2010. Arsip blog Sistem Pendidikan Islam Rabu, 03 November 2010. Satria Hadi Lubis. 2010. Menggairahkan Perjalanan, Halaqah kiat agar halaqah lebih dahsyat full manfaat. Penerbit Pro-U Media. Yogyakarta. 2011., Menggairahkan Perjalanan Halaqah (Cet. II; Yogyakarta: Pro-U Media).

Samsul Nisar. 2007. Sejarah Pendidikan Islam (Menelusuri jejak sejarah pendidikan Era Rasulullah Sampai Indonesia) Jakarta : Kencana.

https:/Dr. Arif Zulkifli Consultan lingkungan dan energy /bangazul.com/kecerdasanspritual/.

http://arnimabruria.blogspot. co.id/2012/08 /aspek-aspek-kecerdasan- emosi .html. 
Penerapan Sistem Pembinaan Halaqah Untuk Meningkatkan Kecerdasan Emosional (Armansyah)

http://arnimabruria. blogspot.co.id /2012/08/ faktor-faktor-yang -mempengaruhi .html.

http://bambang sigit widodo. blogspot.co.id /2010/05/Pentingnya -kecerdasan-emosionaldalam.html.

https: // ukkiunso3d .wordpress. com /2009/ 10/26/ membangun- dan-membentuk-halaqohmuntijahl.

http://belajar psikologi. com/ pengertian -kecerdasan- emosional- eq. 